\title{
EXPERIMENTAL STUDY OF TIMBER-TIMBER COMPOSITE MEMBERS
}

\author{
FARSHID NOURI, MARK A. BRADFORD \& HAMID VALIPOUR \\ Centre for Infrastructure Engineering and Safety, School of Civil and Environmental Engineering, \\ UNSW Sydney, Australia
}

\begin{abstract}
Timber is a sustainable construction material having a higher strength to density ratio, lower embodied energy and a lower carbon footprint when compared with conventional construction materials such as steel and concrete. Furthermore, the advent of engineered wood products including glued laminated timber (Glulam), cross laminated timber (CLT) and laminated veneer lumber (LVL) with improved mechanical properties and dimensional stability has provided the opportunity to construct multi-storey timber buildings with robustness and reliability comparable to steel and reinforced concrete structures, but with far less environmental intrusion. This paper investigates the behaviour of CLT panels connected to LVL and/or Glulam timber joists by coach screws, creating a timber-timber composite (TTC) member. The load-slip behaviour and failure modes of the CLT-LVL and CLT-Glulam composite members are characterised by conducting push-out tests and the effect of the CLT lamellae orientation, screw size and inclination and the edge distance in conjunction with the type of timber joist (LVL, softwood/hardwood Glulam) on the structural behaviour of the TTC members are investigated. Finally, an empirical model for the load-slip response of the TTC members with dowel connections is developed and calibrated from non-linear regression of the push-out test data.

Keywords: cross laminated timber (CLT), load-slip, screw, shear connector, timber-timber composite (TTC).
\end{abstract}

\section{INTRODUCTION}

Timber is a sustainable construction material having a higher strength to density ratio, less embodied energy and a lower carbon footprint than conventional construction materials such as steel and concrete. Furthermore, the advent of engineered wood products including glued laminated timber (Glulam), cross laminated timber (CLT) and laminated veneer lumber (LVL) with improved mechanical properties and dimensional stability has provided the opportunity to construct multi-storey timber buildings with robustness and reliability comparable to those of steel and reinforced concrete structures, yet with much less adverse effect on the environment [1], [2]. Apart from the obvious environmental advantages of timber, in mid- to high-rise buildings, light-weight timber floors can significantly reduce the self-weight of the structure. This attribute in turn can reduce the cost of footings, particularly in construction sites with problematic soil, and it also reduces seismic induced inertia forces. Timber floors with mechanical shear connectors (screws or bolts) can also increase the speed of construction, reduce the cost of labour at construction sites and provide much flexibility in terms of deconstruction, recycling and/or reuse of the construction materials and structural components at the end of the service life of the building.

The structural performance of timber-to-steel composite joints and beams has been comprehensively studied by Hassanieh et al. [3]-[5] and Loss and Davison [6] and Loss et al. [7], but research on timber-to-timber connections mainly focuses on the behaviour, analysis and modelling of dowel type connectors and the structural performance of lap and/or edge joints [8], [9], with less attention being paid to the structural behaviour of timber-totimber composite connections [10], [11]; in particular to CLT-LVL and CLT-Glulam composite connections for the development of prefabricated timber-timber composite (TTC) 
floors. Recently, Branco et al. [12] investigated the in-plane behaviour of traditional timber floors strengthened with CLT panels using SFS, HBS and VGZ screws installed normal and inclined $\left(\right.$ at $\left.45^{\circ}\right)$ to the shear plane.

Due to a dearth of test data on TTC joints with screw connections, the short-term behaviour of CLT-LVL and CLT-Glulam composite joints is evaluated herein by conducting symmetric push-out tests. The failure mode, load-slip response, peak load carrying capacity and stiffness of TTC joints with LVL and softwood/hardwood Glulam beams and with different coach screw sizes, inclination and edge distance are reported and discussed. Nonlinear regression of the push-out test results is then carried out and empirical load-slip formulae for CLT-LVL and CLT-Glulam composite joints with coach screw shear connectors are derived.

\section{EXPERIMENTAL PROGRAM}

Thirteen different TTC push-out specimens (two identical specimens of each TTC type) with symmetric configuration were fabricated and tested. The push-out specimens comprised of two CLT panels connected to either LVL or Glulam (hardwood and softwood) timber joints by coach screws. The main variables in the push-out tests were the type of timber joists (LVL, softwood Glulam, hardwood Glulam), size of the screws (12, 16 and $20 \mathrm{~mm}$ ) and the inclination angle of the screws with respect to the shear or interface plane $\left(45^{\circ}\right.$ and $\left.90^{\circ}\right)$ and the direction of shear/loading with respect to the grain of outer layer of the CLT panels. The loading and geometric configuration, dimensions and details of the push-out specimens and the type of screws are shown in Fig. 1 and in Table 1.

The CLT panels used in the fabrication of the push-out specimens were $120 \mathrm{~mm}$ thick and $400 \mathrm{~mm}$ wide (Fig. 1). The CLT panels were made of five Spruce lamellae of strength class C24 according to BS EN 338 [13]. The mean moisture content (MC) of the panels measured by oven dry testing according to AS/NZS 2098.1 [14] was $\mathrm{MC}=11 \%$ and the mean density of the CLT panels was $500 \mathrm{~kg} / \mathrm{m}^{3}$. The mechanical properties of the CLT panels were as reported in Hassanieh [15] and given in Table 2. In the push-out specimens, the CLT panels were loaded either parallel or perpendicular to the direction of the grain in the outer layers and accordingly the push-out specimens were categorised into two different classes: parallel and perpendicularly loaded (Table 1).
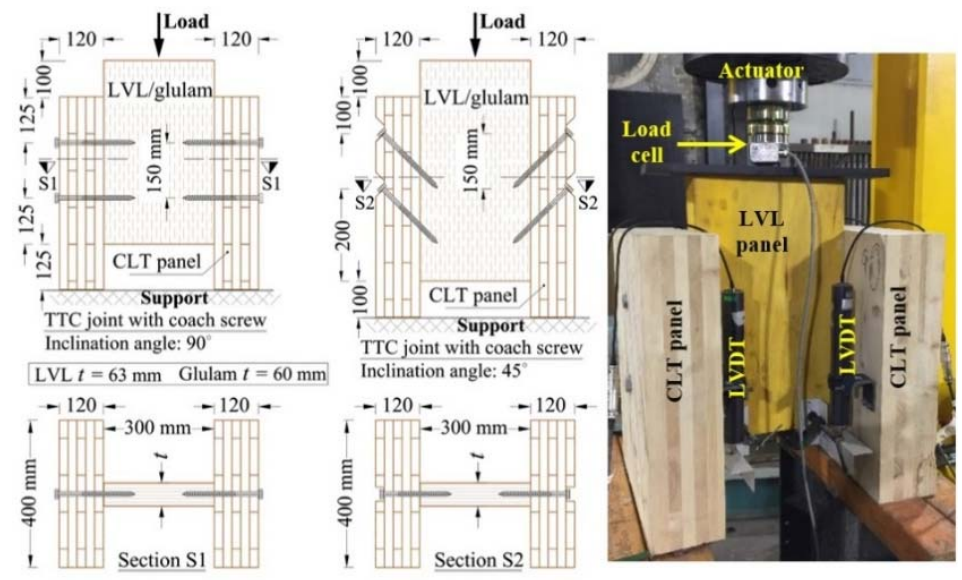

Figure 1: Outline of push-out tests and specimens with $90^{\circ}$ and $45^{\circ}$ coach screw inclination. 
Table 1: Details of push out specimens.

\begin{tabular}{|c|c|c|c|c|}
\hline $\begin{array}{l}\text { Specimen } \\
\text { No. }\end{array}$ & $\begin{array}{l}\text { Connector size } \\
\text { Dia. } \times \text { Length }(\mathrm{mm})\end{array}$ & $\begin{array}{l}\text { Timber joist } \\
\text { type }\end{array}$ & $\begin{array}{l}\text { CLT panel } \\
\text { orientation }^{\#}\end{array}$ & $\begin{array}{l}\text { Screw angle to } \\
\text { shear plane }\end{array}$ \\
\hline 1 & $12 \times 200$ & & & \\
\hline & $\begin{array}{l}16 \times 200 \\
20 \times 200\end{array}$ & LVL & Parallel & $90^{\circ}$ \\
\hline $\begin{array}{l}4 \\
5\end{array}$ & $\begin{array}{l}16 \times 200 \\
20 \times 200\end{array}$ & $\begin{array}{c}\text { Glulam } \\
\text { Pacific Teak }\end{array}$ & Parallel & $90^{\circ}$ \\
\hline $\begin{array}{l}6 \\
7\end{array}$ & $\begin{array}{l}16 \times 200 \\
20 \times 200\end{array}$ & $\begin{array}{c}\text { Glulam } \\
\text { Slash Pine }\end{array}$ & Parallel & $90^{\circ}$ \\
\hline 8 & $12 \times 200$ & & & \\
\hline $\begin{array}{c}9 \\
10\end{array}$ & $\begin{array}{l}16 \times 200 \\
20 \times 200\end{array}$ & LVL & Parallel & $45^{\circ}$ \\
\hline 11 & $12 \times 200$ & & & \\
\hline $\begin{array}{l}12 \\
13\end{array}$ & $\begin{array}{l}16 \times 200 \\
20 \times 200\end{array}$ & LVL & Perpendicular & $90^{\circ}$ \\
\hline
\end{tabular}

\# Direction of loading (shear force) with respect to outer layers of CLT panels.

Table 2: Mechanical properties of CLT panels (in MPa).

\begin{tabular}{ccccccc}
\hline $\begin{array}{c}\text { Bending } \\
\left(f_{b}\right)\end{array}$ & $\begin{array}{c}\text { Tension II to } \\
\text { grain }\left(f_{t}\right)\end{array}$ & $\begin{array}{c}\text { Shear in beams } \\
\left(f_{s}\right)\end{array}$ & $\begin{array}{c}\text { Compression II } \\
\text { to grain }\left(f_{c}\right)\end{array}$ & $\begin{array}{c}\text { Compression L to } \\
\text { grain }\left(f_{p}\right)\end{array}$ & $\begin{array}{c}\text { Elastic modulus } \\
(E)\end{array}$ & $\begin{array}{c}\text { Rigidity } \\
\text { modulus }(G)\end{array}$ \\
\hline 24 & 16.5 & 4.6 & 24 & 2.7 & 12000 & 690 \\
\hline
\end{tabular}

Table 3: Mechanical properties of LVL panels (in MPa).

\begin{tabular}{ccccccc}
\hline $\begin{array}{c}\text { Bending } \\
\left(f_{b}\right)\end{array}$ & $\begin{array}{c}\text { Tension II to } \\
\text { grain }\left(f_{t}\right)\end{array}$ & $\begin{array}{c}\text { Shear in beams } \\
\left(f_{s}\right)\end{array}$ & $\begin{array}{c}\text { Compression II } \\
\text { to grain }\left(f_{c}\right)\end{array}$ & $\begin{array}{c}\text { Compression L to } \\
\text { grain }\left(f_{p}\right)\end{array}$ & $\begin{array}{c}\text { Elastic modulus } \\
(E)\end{array}$ & $\begin{array}{c}\text { Rigidity } \\
\text { modulus }(G)\end{array}$ \\
\hline 50 & 25 & 4.6 & 41 & 12 & 13200 & 660 \\
\hline
\end{tabular}

The LVL panels used in the fabrication of the TTC specimens were $63 \mathrm{~mm}$ thick and the panels were made from Radiata Pine laminated veneers. The mechanical properties of the LVL panels obtained in accordance with the specifications of AS/NZS 4357.0 [16] are given in Table 3. Before testing, the LVL panels had $\mathrm{MC}=11 \%$ and the mean density of the LVL panels was $600 \mathrm{~kg} / \mathrm{m}^{3}$.

Two different Glulam beams, made of Slash Pine (softwood) and Pacific Teak (hardwood) lumbers, were used in the fabrication of the push-out specimens. The Glulam beams were $60 \mathrm{~mm}$ wide and $300 \mathrm{~mm}$ deep. The average moisture content of the specimens obtained from oven dry testing was $\mathrm{MC}=10 \%$. The mean density of the Slash Pine and Pacific Teak Glulam beams were $690 \mathrm{~kg} / \mathrm{m}^{3}$ and $780 \mathrm{~kg} / \mathrm{m}^{3}$ respectively, while the elastic modulus of Slash Pine and Pacific Teak Glulam beams were 12.6 and $14.3 \mathrm{GPa}$ respectively. Hexagonal coach screws having 12, 16 and $20 \mathrm{~mm}$ diameters were used in the fabrication of the specimens. The overall length of coach screws was $205-210 \mathrm{~mm}$ and the coach screws were made of Grade 4.6 steel with characteristic yield and ultimate strengths of $240 \mathrm{MPa}$ and $400 \mathrm{MPa}$ respectively. Uniaxial tension tests were conducted on three identical screws and the stressstrain response and mechanical properties of the screws were determined. The mean yield and ultimate strength and elastic modulus of the tested screws were $305 \mathrm{MPa}, 430 \mathrm{MPa}$ and $195 \mathrm{GPa}$ respectively. 
To facilitate the testing, to minimise the unwanted friction between the CLT panel and LVL/Glulam beams and to achieve a relatively uniform load distribution along the connectors, a symmetric configuration was used for the push-out specimens. The CLT panels and LVL/Glulam joists were pre-drilled to facilitate the installation of coach screw shear connectors and to minimise the risk of splitting the LVL/Glulam beams. The diameter of predrilled holes was $2 \mathrm{~mm}$ smaller than the diameter of the coach screw shear connectors. Each CLT panel was connected to the timber joists by two coach screws (Fig. 1). The two coach screw shear connectors on each side of the push-out specimens were $150 \mathrm{~mm}$ apart (Fig. 1), that complies with the minimum spacing requirements of $7 d_{s}\left(d_{s}=\right.$ screw shank) for the inclined screws [17].

The relative displacement (slip) between the CLT panels and LVL/Glulam beams was measured by four linear variable displacement transducers (LVDTs) having a maximum stroke of $100 \mathrm{~mm}$ mounted on four sides of each specimen (Fig. 1). The relative slips measured by the four LVDTs were also used to ensure that the specimens were not tilting or twisting during the tests. An actuator with a capacity of $500 \mathrm{kN}$ was used to apply the load in the vertical direction on the LVL/Glulam joists as shown in Fig. 1.

The loading regime for push-out tests followed the protocol specified in BS EN 268911991 [18], consisting of three stages. In the first stage, the specimen was loaded up to $40 \%$ of the estimated ultimate strength $F_{\text {est }}$ in 120 seconds and the load remained steady at $0.4 F_{\text {est }}$ for 30 seconds. In the second stage, the specimen was unloaded to $0.1 F_{\text {est }}$ in 120 seconds and maintained at $0.1 F_{\text {est }}$ for 30 seconds. In the final stage, the specimen is reloaded up to $70 \%$ of the ultimate load carrying capacity using a load-controlled regime, and then testing was conducted under a displacement-controlled regime (with a rate of $2 \mathrm{~mm} / \mathrm{s}$ ) until the onset of failure. The ultimate strength of the TTC joints in the current study was estimated using the European Yield Model (EYM) considering the plastic behaviour of the timber and mechanical fasteners [18].

\section{DISCUSSION OF TEST RESULTS}

Assuming a single shear plane for each mechanical fastener connecting the two timber components in TTC joints with unequal embedment strengths and different thickness $\left(f_{e 1}, f_{e 2}\right.$, $t_{1}$, and $t_{2}$ ), six distinctive failure modes can be identified in general as shown in Fig. 2. The occurrence of each failure mode depends on the embedment strength of the timber components, the effective thickness of each component (or embedment length of the fastener) and the yield moment (strength) of the mechanical fasteners. The first two modes of failure (Modes I and II) are associated with lateral crushing of the timber (either in the CLT or LVL/Glulam joists) near the mechanical connectors without significant deformation in the shear connectors. In failure Mode III, lateral yielding occurs in both timber components simultaneously. The failure Modes IV and V are associated with formation of only one plastic hinge within the shear connectors, whereas in Mode VI two plastic hinges develop within the connectors. The failure modes I to III are brittle, but modes IV to VI can be categorised as ductile modes of failure. Apart from the six distinctive failure modes shown in Fig. 2, possible splitting of the timber joists and withdrawal of the coach screws should be also considered as separate failure modes.

The TTC specimens tested in this study mostly exhibited two failure modes, i.e. Modes V and VI, depending on the size and inclination angle (i.e. $90^{\circ}, 45^{\circ}$ ) of the coach screw shear connectors, as in Fig. 3. However, in TTC joints with inclined $\left(45^{\circ}\right)$ coach screw shear connectors, only failure Mode V was observed irrespective of the screw size. Furthermore, in the TTC joints with inclined screws, signs of withdrawal failure (i.e. separation of the CLT 

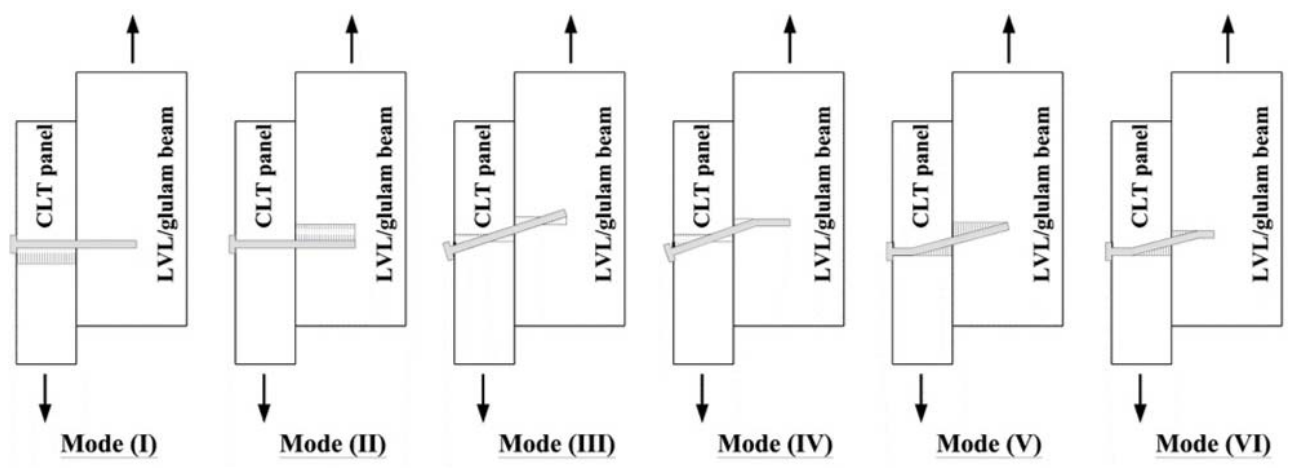

Figure 2: Different modes of failure in TTC joints.

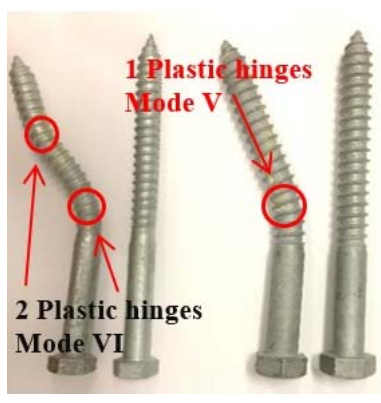

(a)

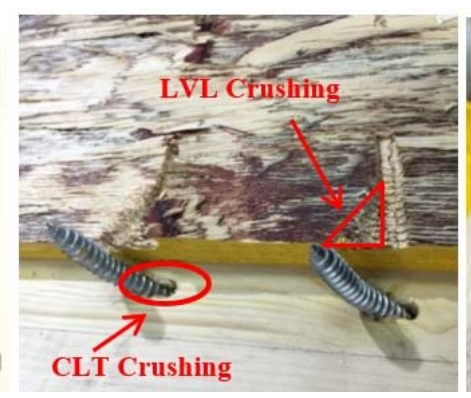

(b)

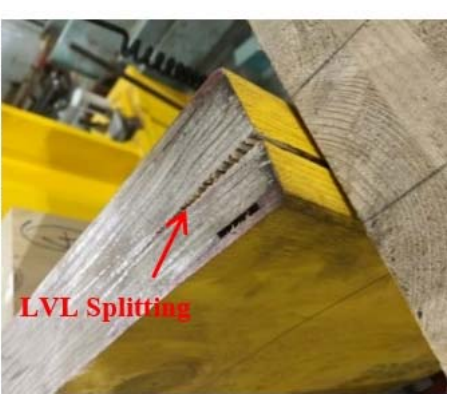

(c)

Figure 3: (a) Development of plastic hinges in $12 \mathrm{~mm}$ and $20 \mathrm{~mm}$ coach screw shear connectors; (b) Lateral crushing of CLT and LVL in failure Mode V; and (c) Splitting of LVL joist in TTC joint with $20 \mathrm{~mm}$ coach screw shear connectors.

panel from the LVL joist) was observed at later stages of the push-out tests. The failure modes of all TTC joints are summarised in Table 4.

In TTC joints with large diameter coach screws, apart from lateral crushing of the timber and plastic deformation in the coach screw shear connectors, splitting of the timber joist and withdrawal of the shear connectors were also observed during large slips exceeding $30 \mathrm{~mm}$ (Fig. 5(c)). In TTC joints with softwood Glulam (Slash Pine) and LVL joists, splitting of timber was only evident in specimens with $20 \mathrm{~mm}$ coach screw shear connectors (edge distance

$<1.6 d_{s}$ ). However, in TTC joints with hardwood Glulam (Pacific Teak) joists, splitting of the joist was observed in specimens with 16 and $20 \mathrm{~mm}$ screws (edge distance $<1.9 d_{s}$ ). Considering the width of the LVL joists $(63 \mathrm{~mm})$ and Glulam joists $(60 \mathrm{~mm})$, it was concluded that the minimum edge distance of $2 \mathrm{ds}$ specified in the timber design code EC5 [17] can adequately safeguard the composite connections between CLT and LVL/Glulam joists against splitting.

The experimental load-slip behaviour of two identical CLT-LVL symmetric joints with S12 and S16 coach screw shear connectors (in total four plots for each shear connector size) is shown in Fig. 4 to demonstrate the variability of the push-out test results. The coefficient 
88 High Performance and Optimum Design of Structures and Materials III

Table 4: Mean ultimate strength, ultimate slip and serviceability slip modulus $k_{s}, 0.6$.

\begin{tabular}{ccccc}
\hline $\begin{array}{c}\text { Specimen } \\
\text { No. }\end{array}$ & $\begin{array}{c}\text { Mean ultimate strength } \\
(\mathrm{kN})\end{array}$ & $\begin{array}{c}\text { Mean ultimate slip } \\
(\mathrm{mm})\end{array}$ & $\begin{array}{c}\text { Slip modulus } k_{\mathbf{5}, 0.6} \\
(\mathrm{kN} / \mathrm{mm}))^{*}\end{array}$ & $\begin{array}{c}\text { Failure mode } \\
(\text { Fig. 3) }\end{array}$ \\
\hline 1 & 19.0 & 34.5 & 0.91 & VI \\
2 & 23.6 & 21.5 & 1.87 & VI \\
3 & 27.7 & 31.0 & 2.27 & $\mathrm{~V}$ \\
4 & 26.4 & 30.5 & 2.87 & $\mathrm{VI}$ \\
5 & 31.9 & 23.5 & 3.10 & $\mathrm{~V}$ \\
6 & 21.9 & 30.9 & 2.88 & $\mathrm{VI}$ \\
7 & 27.3 & 24.1 & 1.79 & $\mathrm{~V}$ \\
8 & 15.3 & 5.4 & 6.87 & $\mathrm{~V}$ \\
9 & 17.3 & 6.9 & 5.38 & $\mathrm{~V}$ \\
10 & 20.9 & 7.8 & 6.07 & $\mathrm{VI}$ \\
11 & 17.9 & 37.5 & 0.80 & $\mathrm{VI}$ \\
12 & 19.7 & 30.3 & 1.63 & $\mathrm{~V}$ \\
\hline 13 & 26.2 & 25.9 & 1.73 & \\
\hline
\end{tabular}

\# The slip modulus $k_{3,0.6}$ is slope of line between $10 \%$ and $60 \%$ of peak load capacity.

\#\# Splitting of timber joist with large slips observed in TTC joints with $20 \mathrm{~mm}$ coach screw shear connectors. Failure mode $\mathrm{V}$ in TTC joints with inclined screws associated with withdrawal of 16 and $20 \mathrm{~mm}$ coach screws.

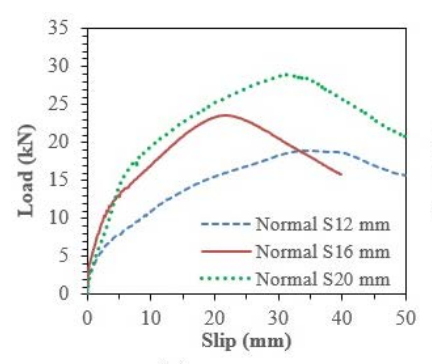

(a)

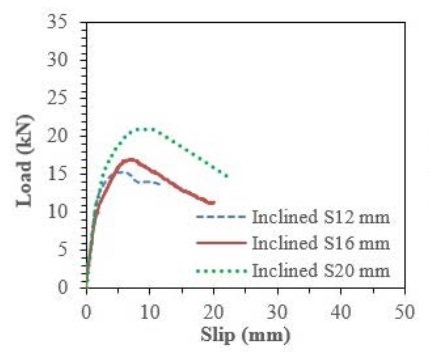

(c)

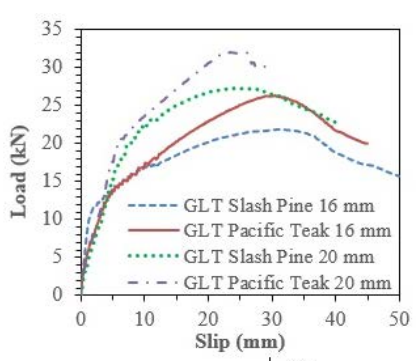

(b)

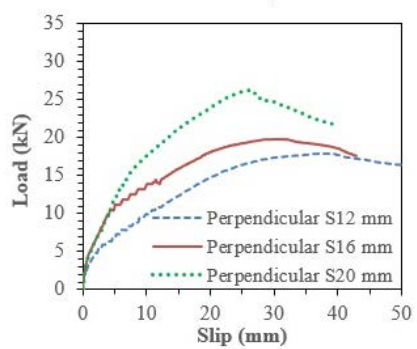

(d)

Figure 4: Mean of experimental load-slip plots for specimens. (a) No. 1-3; (b) No. 4-7; (c) No. 8-10; and (d) No. 11-13.

of variation $(\mathrm{CoV})$ for joints with $\mathrm{S} 12, \mathrm{~S} 16$ and $\mathrm{S} 20$ shear connectors were 5.5\%, 2.2\% and $4.2 \%$, respectively. The mean of the experimental load-slip plots for all TTC joints are shown in Fig. 5. Furthermore, the mean of the peak load carrying capacity, the slip corresponding to the peak load capacity and the serviceability slip modulus $k_{s}, 0.6$ for the TTC joints are given in Table 4 . The serviceability slip modulus $k_{s}, 0.6$ refers to the slope of the line between $10 \%$ and $60 \%$ of the peak load capacity. The maximum CoV for all tested specimens was limited to $5.5 \%$ which corresponded to the CLT-LVL composite joint with S12 screw shear connectors. 


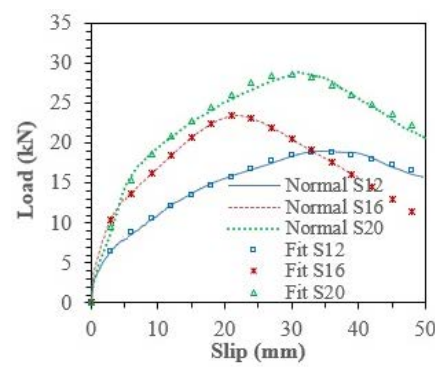

(a)

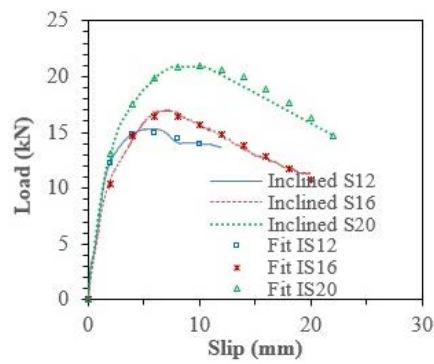

(c)

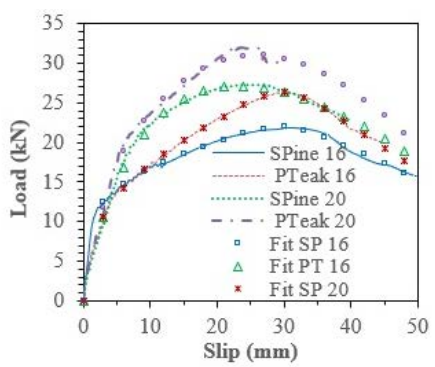

(b)

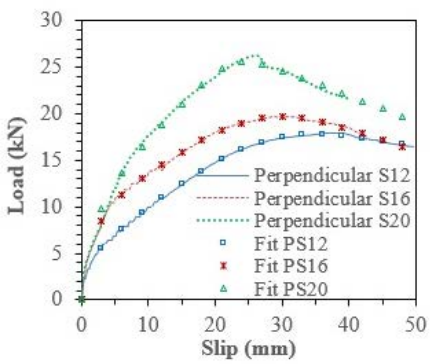

(d)

Figure 5: Correlation between empirical model and mean of experimental load-slip for (a) Parallel CLT-LVL connections; (b) Perpendicular CLT-LVL connections; (c) CLT-Glulam connections; and (d) Inclined CLT-LVL connections.

\section{ANALYTICAL MODEL}

An empirical load-slip model proposed by Hassanieh et al. [4] was calibrated against the experimental push-out tests by means of non-linear regression. The proposed model has seven parameters comprising three asymptotic lines that can represent the ascending and descending parts of the TTC load-slip behaviour by a single function. The load-slip function $f(s)$ is given by

$$
f(s)=\frac{\left(k_{0}-k_{p}\right) s}{\left\{1+\left[\left(k_{0}-k_{p}\right) \frac{s}{f_{0}}\right]^{n_{1}}\right\}^{\frac{1}{n_{1}}}}+\frac{\left(k_{p}+k_{s}\right) s}{\left\{1+\left[\left(k_{p}+k_{s}\right) \frac{s}{f_{1}-f_{0}}\right]^{n_{2}}\right\}^{\frac{1}{n_{2}}}}-k_{s} s,
$$

where $k_{0}, k_{p}$ and $k_{s}$ are the initial, pre-peak and post-peak stiffnesses of the load-slip curve respectively, $f_{0}$ and $f_{1}$ the first and second reference shear forces corresponding to the prepeak and post-peak branches, and $n_{1}$ and $n_{2}$ control the curvature of the load-slip curve before and after the peak respectively. The non-linear regression scheme in MATLAB with the trust region algorithm accompanied with bi-square robustness was used to determine the seven parameters of the empirical model with best fit to the experimental load-slip results. The seven input parameters for establishing the empirical load-slip model of the CLTLVL/Glulam composite joints with coach screw shear connectors are given in Table 5. The goodness-of-fit and close correlation between the analytical model and experimental data is evident from the R-square values given in Table 5 and the load-slip curves shown in Fig. 6. 
Table 5: Input parameters for analytical model.

\begin{tabular}{ccccccccc}
\hline Specimen No. & $f_{0}$ & $f_{1}$ & $k_{0}$ & $k_{\mathrm{p}}$ & $k_{\mathrm{s}}$ & $n_{1}$ & $n_{2}$ & $R^{2}$ \\
\hline 1 & 40.7 & 58.94 & 50.00 & 0.21 & 0.33 & 0.27 & 10.00 & 0.9960 \\
2 & 16.21 & 39.94 & 35.00 & 0.58 & 0.54 & 0.51 & 11.96 & 0.9996 \\
3 & 15.00 & 43.81 & 3.416 & 0.54 & 0.44 & 2.56 & 9.92 & 0.9959 \\
\hline 4 & 14.88 & 45.89 & 6.97 & 0.45 & 0.58 & 1.15 & 14.83 & 0.9985 \\
5 & 11.42 & 130.1 & 4.00 & 1.41 & 1.54 & 5.01 & 1.61 & 0.9934 \\
6 & 17.7 & 37.44 & 43.94 & 0.23 & 0.42 & 0.62 & 13.00 & 0.9995 \\
7 & 10.00 & 120.5 & 35.00 & 4.99 & 0.99 & 0.00 & 0.77 & 0.9962 \\
8 & 16.4 & 17.25 & 12.6 & 5.00 & 0.32 & 2.59 & 17.3 & 0.9936 \\
9 & 7.62 & 21.3 & 8.31 & 2.00 & 0.53 & 1.92 & 4.08 & 0.9964 \\
10 & 50.00 & 54.72 & 8.99 & 1.61 & 1.22 & 0.94 & 6.44 & 0.9972 \\
11 & 10.00 & 27.68 & 59.99 & 0.43 & 0.16 & 0.35 & 5.59 & 0.9992 \\
12 & 12.87 & 30.6 & 8.00 & 0.33 & 0.28 & 0.86 & 6.91 & 0.9987 \\
13 & 25.00 & 43.82 & 20.00 & 0.48 & 0.34 & 0.47 & 20.71 & 0.9947 \\
\hline
\end{tabular}

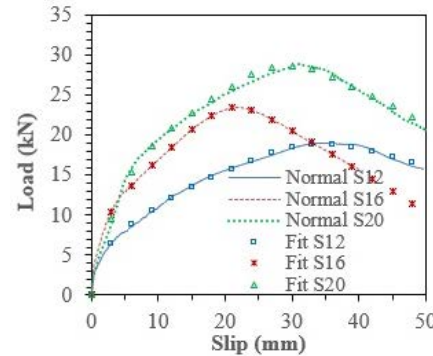

(a)

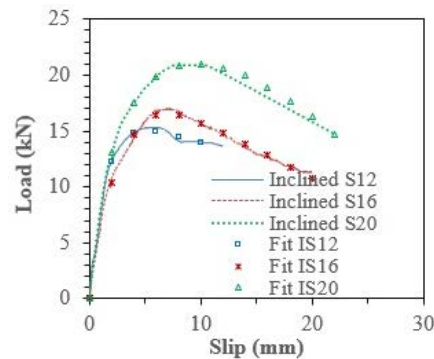

(c)

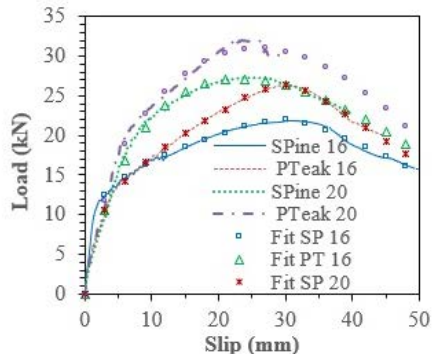

(b)

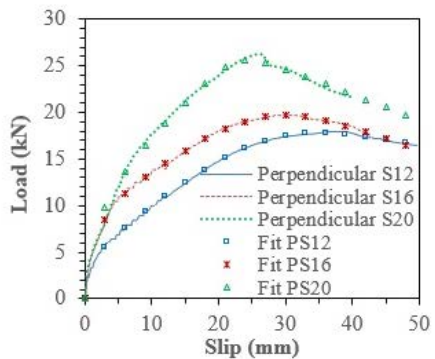

(d)

Figure 6: Correlation between empirical model and mean of experimental load-slip for (a) Parallel CLT-LVL connections; (b) Perpendicular CLT-LVL connections; (c) CLT-glulam connections; and (d) Inclined CLT-LVL connections.

\section{CONCLUSIONS}

The results of push-out tests on CLT-LVL and CLT-Glulam composite joints with coach screw shear connectors were reported and effect of the Glulam type (softwood or hardwood), shear connector size (S12, S16 and S20) and inclination angle of the screws $\left(90^{\circ}, 45^{\circ}\right)$ and orientation of load with respect to the outer lamellae of the CLT panel (parallel and perpendicular to the grain) on the serviceability stiffness, ultimate strength and load-slip behaviour of the TTC joints were investigated. The following conclusions can be drawn from the results of laboratory push-out experiments on the TTC joints: 
- The dominant failure mode in CLT-LVL composite joints with inclined coach screw shear connectors was associated with lateral crushing of the timber and the development of one plastic hinge within the connectors' length embedded in the CLT panel. However, in the failure mode of CLT-LVL/Glulam joints with normal coach screw shear connectors, either one plastic hinge formed in the connectors' length embedded in the CLT panel or two plastic hinges developed within the length of the connector.

- The orientation of the outer lamellae of the CLT panel with respect to the direction of loading affected the stiffness of CLT-LVL composite joints by $13 \%$ to $24 \%$ and the ultimate strength of the CLT-LVL joints by $6 \%$ to $16 \%$.

- Depending on the diameter of the coach screw shear connectors, the serviceability stiffness of the CLT-LVL joints with inclined shear connectors was 2.67 to 7.55 times higher than identical joints with normal shear connectors.

- Using hardwood Glulam instead of softwood Glulam in CLT-Glulam composite joints with normal coach screw shear connectors increased the ultimate strength by $17 \%$ to $21 \%$, depending on the size of screws. Furthermore, a maximum $76 \%$ enhancement in the serviceability stiffness of the CLT-Glulam joints were achieved when softwood Glulam joists were replaced by hardwood Glulam joists.

\section{REFERENCES}

[1] Picard, N., Saint-André, L. \& Henry, M., Manual for Building Tree Volume and Biomass Allometric Equations: From Field Measurement to Prediction, Food and Agricultural Organization of the United Nations: Rome, 2012.

[2] Sathre, R. \& O'Connor, J., A synthesis of research on wood products and greenhouse gas impacts, Report No. TR-19R, FPI Innovations: Vancouver, 2010.

[3] Hassanieh, A., Valipour, H.R. \& Bradford, M.A., Load-slip behaviour of steel-cross laminated timber (CLT) composite connections. Journal of Constructional Steel Research, 122, pp. 110-121, 2016.

[4] Hassanieh, A., Valipour, H.R. \& Bradford, M.A., Experimental and analytical behaviour of steel-timber composite connections. Construction and Building Materials, 118, pp. 63-75, 2016.

[5] Hassanieh, A., Valipour, H.R. \& Bradford, M.A., Experimental and numerical investigation of short-term behaviour of CLT-steel composite beams. Engineering Structures, 144, pp. 43-57, 2017.

[6] Loss, C. \& Davison, B., Innovative composite steel-timber floors with prefabricated modular components. Engineering Structures, 132, pp. 695-713, 2017.

[7] Loss, C., Piazza, M. \& Zandonini, R., Connections for steel-timber hybrid prefabricated buildings. Part I: Experimental tests. Construction and Building Materials, 122, pp. 781-795, 2015.

[8] Girhammar, U.A., Jacquier, N. \& Källsner, B., Stiffness model for inclined screws in shear-tension mode in timber-to-timber joints. Engineering Structures, 136, pp. 580595, 2017.

[9] Uibel, T. \& Blass, H., Edge joints with dowel type fasteners in cross laminated timber. Report No. Proceedings. CIB-W18 Meeting, paper 40-7-2, Bled, Slovenia, 2007.

[10] Tomasi, R., Crosatti, A. \& Piazza, M., Theoretical and experimental analysis of timberto-timber joints connected with inclined screws. Construction and Building Materials, 24(9), pp. 1560-1571, 2010.

[11] Jacquier, N. \& Girhammar, U.A., Tests on glulam-CLT shear connections with double-sided punched metal plate fasteners and inclined screws. Construction and Building Materials, 72, pp. 444-457, 2014. 
92 High Performance and Optimum Design of Structures and Materials III

[12] Branco, J.M., Cruz, P.J.S. \& Piazza, M., Experimental analysis of laterally loaded nailed timber-to-concrete connections. Construction and Building Materials, 23(1), pp. 400-410, 2009.

[13] BS EN 338: Structural Timber. Strength Classes, British Standards Institution: London, 2016.

[14] AS/NZS 2098.1 Methods of Test for Veneer and Plywood. Moisture Content of Veneer and Plywood, Standards Australia: Sydney, 2016.

[15] Hassanieh, A., Development of Steel-Timber Composite System for Large Scale Construction. PhD thesis, The University of New South Wales, UNSW Sydney, 2017.

[16] AS/NZS 4357.0 Structural Laminated Veneer Lumber, Standards Australia: Sydney, 2016.

[17] Eurocode 5, Design of Timber Structures - Part 1-1: General - Common Rules and Rules for Buildings, BS EN 1995-1-1, British Standards Institution: London, 2014.

[18] BS EN 26891, Timber Structures. Joints made with Mechanical Fasteners. General Principles for the Determination of Strength and Deformation Characteristics, British Standards Institution: London, 1991. 